\title{
QUANTITATIVE ASSESSMENT OF URBAN TRANSPORT DEVELOPMENT - A SPATIAL APPROACH
} pages: $32-44$

\author{
Artur CZeCh, ANNA Biezdudnaja, Jerzy LeWCZUK, \\ WŁADIMIR RAZUMOWSKIJ
}

Corresponding author:

\begin{abstract}
A B S T R A C T
Urban transport is considered the basis of properly functioning cities and their development. The main aim of the paper is to attempt the assessment of urban transport development in selected voivodeships (provinces) as a crucial factor of macro logistics. The research also aimed to identify the underdeveloped areas of urban transport in Poland as the basis for the implementation of support policy. The source of information in the investigation process was data drawn from the Central Statistical Office in Poland for 2013-2016. In the scope of dealing with the research problem, chosen classical and order multivariate statistical measures were implemented into the research process. Next, the taxonomic measures for the years of interest served as the basis for the construction of the total (general) synthetic measure applicable to the entire period. The main results and findings of the research indicate that the level of urban transport development is correlated with the whole transportation system which affects the socio-economic development of some regions of Poland. The research can lead to a better understanding of Polish urban transportation development in selected regions. Hence, the results can be helpful in the investment process and for shaping the right transportation policy to improve the use of financial resources.
\end{abstract}

KEY WORDS

cities, urban transport, voivodeships, synthetic measure, variable

DOI: 10.1515/emj-2018-0003
Artur Czech

Bialystok University of Technology, Faculty of Engineering Management, Poland e-mail: a.czech@pb.edu.pl

Anna Biezdudnaja

Saint-Petersburg State University of Economics, Faculty of Management, Russia e-mail: dept.kmi@unecon.ru

Jerzy Lewczuk

Bialystok University of Technology, Faculty of Engineering Management, Poland e-mail: j.lewczuk@pb.edu.pl

Władimir Razumowskij

Saint-Petersburg State University of Economics, Faculty of Humanities, Russia e-mail: dept.krep@unecon.ru

\section{INTRODUCTION}

The accession of Poland to the European Union obligated the introduction of required policies to improve the development level of the whole country as well as its regions. Poland is diverse, and this is reflected in the level of socio-economic development of voivodeships. These regions have large disparities among regions. Among others, this situation depends on the size of a settlement, i.e. an urban area.

Cities generate many positive external effects, e.g. they are considered both the heart of the economy and its driving forces. They are treated as human, economic, technological and cultural centres. As most of the highly remunerated professions concentrate in the largest urban areas (Kozera et al., 2014); this tendency affects the distribution of wealth among 
local administrative regions (Madras \& Mitura, 2014). Hence, it should be noted that the value of a region value depends on its cities (Cheba \& Saniuk, 2015).

On the other hand, transportation systems of urban areas also have negative effects, such as congestion, air pollution, traffic noise, etc. (Gratiela, 2013).

All of the effects are strictly determined by the quantity and quality of delivered public services in the urban areas of voivodeships. Moreover, the potential and the level of the regional development are mainly determined by the existing urban transportation systems, which influence the quality of life.

Urban transport relationships are mutual and very hard to quantify because urban transport can be considered as a complex phenomenon where indirectly observable interactions and relations play a key role.

Therefore, it is necessary to make a reliable diagnosis of the development level of urban infrastructure and its changes as one of the measures of socio-economic development of selected areas in Poland.

The paper aims to assess the state and changes of urban transport development in selected voivodeships as the important factors of the macro logistic system of the country. Also, the article aims to identify the regions underdeveloped in the research field.

The elaboration was based on the literature studies and multidimensional analysis using the chosen taxonomic methods.

\section{LITERATURE REVIEW}

The literature review showed that transport is considered as the basis of our economy and society. The mobility is very important to the internal market as well as the quality of life of the citizens who can freely travel (European Commission, 2011). Furthermore, it is perceived as a universal and irreplaceable element of both economic and social processes. Therefore, the transportation system is considered as a factor that influences regional development, settlement network, production location, etc. (Liberadzki, 2013). Moreover, transport plays a key role in the strategy development for cross-border regions (Mun \& Nakagava, 2010; Lewczuk \& Ustinovichius, 2015) and is especially important for cooperation with other countries and regions (Ustinovichius et al., 2017).
All in all, policies ensuring the availability of a properly developed transport infrastructure is one of the basic fields of activity of a state. The mobility of people and things is ensured by infrastructure whose maintenance and modernisation mean incurring high financial costs (Paprocki, 2013).

Nowadays, transport is considered to be one of the corner stones of globalisation (Kumar \& Hoffmann, 2002). Globalisation and investment processes of a modern world can and should influence multifaced regional development including the transport industry (Максимцев et al., 2017) where innovative investments play a key role in the economic life. The implementation and development of technical infrastructure is not possible without meaningful investment projects (Бездудная el al., 2016).

Transport accessibility and connectivity are considered an important factor affecting investments in big cities, e.g. Wrocław (Ignacy, 2016). One of the EU documents, namely the Green Paper, states that citizens expect quality, effectiveness and accessibility form the public transport. The public transport, which is considered attractive, is not only accessible but also fast, reliable, comfortable and offers frequent connections (Solecka, 2011). In the case of cities, all of these issues are strictly connected with overcoming barriers that hinder the smooth functioning of traffic, e.g. congestion (Cheba, 2015).

All in all, public transport as an element of the national logistics system can be considered a complex and multidimensional phenomenon. Consequently, in the area of the logistics infrastructure, urban public passenger transport has to achieve aims that contradict one another (Korczak \& Kijewska, 2016).

Hence, selecting indicators for the research of the transportation system is considered an extremely difficult issue mainly due to the wide variety of indicators and its multidimensionality (Cheba \& Saniuk, 2016; Persia et al., 2016). Nevertheless, it is worth mentioning the descriptors (features) that are commonly used for the construction of spatial models for passenger and freight transport, such as the density of inhabitants, the accessibility and connectivity of the work network, spatial location, distance and different types of routes, the width of streets (Ewing \& Cervero, 2001; Stead \& Marshial, 2001; Sanchez-Diaz et al., 2014) as well as economic variables, such as population incomes (Ducret et al., 2015). The literature review found the following variables used in urban infrastructure research: the total length of roads to 
the city area, the ratio of asphalt roads to the total roads, the ratio of asphalt roads for every 100000 people, the ratio of city roads to the area of the province, the ratio of inter-city roads to the area of the city, and the ratio of main roads to the area of a city. All the features were the basis of the assessment process of regional development of border cities (Fanni et al., 2014).

The research problem can be addressed using two different approaches.

An analysis can be carried out according to separate and single variables. This is a one-dimensional approach. It can be considered defective because of difficulties in a clear assessment of analysed objects.

The use of multivariate tools creates a possibility to support the logistics policy by implementing the ordering and classification procedures for research objects which are described by the set of diagnostic variables (Figura, 2013).

On the one hand, the empirical investigations with taxonomic tool have already been introduced into the analysis of transport development in the European Union countries (Tarka, 2012; Strojny, 2013; Kauf \& Tłuczuk, 2014). Some of them dealt with urban transportation system problems in selected European cities (Hajduk, 2016) and were proceeded by literature studies on urban transport (Hajduk, 2017). All in all, the mentioned analysis generally used classical taxonomic tools, e.g. linear ordering which uses the arithmetic mean and standard deviation in its construction.

The further analysis of the condition of transport using the order version of linear ordering tools was carried out among the chosen European Union countries in areas of road, railway and air transport as the three main branches of the transportation system (Czech \& Lewczuk, 2017). This taxonomic study was deepened with the implementation of different normalisation methods based on the multidimensional Weber median (Czech et al., 2016). All in all, these analyses allowed making the research immune to the empirical asymmetry of diagnostic variables. Additionally, the implementation of the Weber median allowed considering mutual interactions among diagnostic features, which is very important in the case of a complex phenomenon analysis such as the transportation system.

On the other hand, the literature study proved that taxonomic methods were also introduced into the research of the road and railway transport development in Polish voivodeships (Cheba, 2011; Jarocka \& Glińska, 2017). All the investigations were based mainly on no-pattern classic taxonomic methods which do not consider the interactions in a complex transportation system. Moreover, the research was distorted as the result of skewness of diagnostic features. Hence, to improve the investigation in such an important research field, the Weber median was introduced in the process of the synthetic measure construction (Czech \& Lewczuk, 2016). It should be noted that this kind of multivariate median considers interactions. However, the issue of including indirect effects is very important in the case of transportation research in different fields (Hayashi \& Morisugi, 2000; Jahanshahi et al., 2015; Matteis et al., 2016; Ward et al., 2016). It should be noted that this research problem is under investigation among experts, and a consensus has not yet been reached (Vörös et al., 2015).

It is worth mentioning that the analysis did neither consider the technological progress in the materials used for the transport infrastructure construction nor its future trends. This issue is crucial because the technological progress that accelerates processes of globalisation is also attributed to the area of transportation (Kherbash \& Liviu Mocan, 2015).

Therefore, the transportation system has already been analysed with future-oriented methods, such as foresight (Ejdys et al., 2015). The area of road transportation in combination with environmental protection has been in the spotlight of the interdisciplinary research (Radziszewski et al., 2016). The reason behind such a combination is a significant impact on the quality of life of people inhabiting urban areas as urban infrastructure undergoes the amortisation process much quicker.

To sum up the literature review, it should be noted that there is a lack of multidimensional analysis of urban transport development in Polish cities of some voivodeships, which considers its complex character. However, the existing multidimensional analysis does not include the mutual relations and interactions among particular areas of urban infrastructure, technical resources, etc. Moreover, the research gap is also connected with the construction of the urban transport development model over the entire period. Hence, this kind of taxonomic research could have some positive impact on the correctness of the delivered analysis in the area of the urban transportation system and support of investment decisions as well as the use of tools ensuring greater sustainability of the urban transport (Malasek, 2016). It is also important to form the point of view regarding the trend to decentralise govern- 
ment decisions to the local level, properly manage the public urban demand (Puppim de Oliveira et al., 2015) as well as the growing urban populations considering the lack of roads, public transport and nonmotorised transport infrastructures (Ahmad \& Puppim de Oliveira, 2016).

\section{THEORETICAL BASIS FOR THE IMPLEMENTED RESEARCH METHODS AND THE SELECTION OF THE DATA SET AND THE TYPE OF THE TOTAL TAXONOMIC MODEL}

The presented research focused on the evaluation of urban transport development based on the construction of the synthetic measure using two basic ways.

The first way implements the classic statistical measures, such as arithmetic mean and standard deviation. This kind of algorithm was first introduced by Polish statistician Hellwig (1968). The synthetic measure is calculated using the following equation:

$$
M K_{i}=1-\frac{d_{i}}{\bar{D}+2 * S_{D}}
$$

where: $\bar{D}$ - mean of the distance vector,

$S_{D}-$ the standard deviation of the distance vector.

The second approach to the construction of the synthetic measure includes the multidimensional median vector as well as mad (median absolute deviation). It is worth noting that this method was also first implemented by a Polish statistician (Lira et al., 2002).

The normalisation process is usually carried out in the form of standardisation according to the following formula:

$$
z_{i j}=\frac{x_{i j}-\theta_{j}}{1,4826 * \operatorname{mad}\left(X_{j}\right)}
$$

The elements of $\theta_{j}$ are considered as the values of the multidimensional median vector, which usually takes the form of the border or the Weber median. The values of the Weber median are assessed in the minimisation process of the following objective function:

$$
T\left(\Theta, R^{m}\right)=\arg \min _{\Theta \in R^{m}}\left\{\sum_{i=1}^{n}\left[\sum_{j=1}^{m}\left(x_{i j}-\theta_{j}\right)^{2}\right]^{1 / 2}\right\}
$$

Besides immunising the analysis to skewness, this multidimensional median vector considers interactions in the whole set of diagnostic variables, which is especially important from the point of view of the taxonomic analysis of a complex phenomenon, such as the socio-economic development, the living standard, spatial cohesion, etc. More detailed information about its history and the way of estimation has already been presented in the literature (Młodak, 2009). Nevertheless, it should be mentioned that other forms of multidimensional median construction which consider interactions among variables are under investigation (Domański et al., 1998).

In relation to mad (median absolute deviation), it should be noted that its particular values are received using the following equation:

$$
\operatorname{mad}\left(X_{j}\right)=\underset{i=1,2, \ldots, n}{\operatorname{med}}\left|x_{i j}-\theta_{j}\right|
$$

Also, it should be mentioned that there are other normalisation methods in the literature and they were successfully implemented into the research process with classic statistical measures (Jajuga \& Walesiak, 2000; Dębkowska \& Jarocka, 2013; Olszewska \& Gudanowska, 2014) and the multidimensional median vector (Czech, 2014; Czech et al., 2016).

The synthetic measure of the normalised variable is estimated using the following formula:

$$
M P_{i}=1-\frac{d_{i}}{\operatorname{med}(D)+2,5 \operatorname{mad}(D)}
$$

where: $\operatorname{med}(D)-$ the median of the distance vector, $\operatorname{mad}(D)$ - the median absolute deviation of the distance vector.

The basis of every proper taxonomic analysis is a set of diagnostic variables. Hence, the data was drawn from the Local Data Bank of the CSO (Central Statistical Office) in Poland for 2013-2016. The set of the following twelve potential diagnostic variables was treated as the research basis: $X_{1}-$ the length of bicycle paths in kilometres per $10000 \mathrm{~km}^{2}, X_{2}-$ the length of bicycle paths in kilometres per 10000 citizens, $X_{3}$ - the length of bus lanes in kilometres per one million urban citizens, $X_{4}-$ the number of public transport passengers per one inhabitant of urban areas, $X_{5}$ - the length of the public transport line in kilometres per 10000 urban citizens, $X_{6}-$ the length of the public transport line in the countryside in kilometres per 10000 inhabitants of the total population, $X_{7}$ - the length of bus routes in kilome- 
Tab. 1. Spatial and time classic variation coefficients of the potential set of diagnostic variables

\begin{tabular}{|c|c|c|c|c|c|c|c|c|c|c|c|c|}
\hline & $x_{1}$ & $x_{2}$ & $x_{3}$ & $x_{4}$ & $x_{5}$ & $x_{6}$ & $x_{7}$ & $x_{8}$ & $X_{g}$ & $x_{10}$ & $x_{11}$ & $x_{12}$ \\
\hline \multicolumn{13}{|c|}{ SPATIAL VARIABILITY } \\
\hline 2013 & 44.61 & 41.77 & 84.48 & 49.22 & 41.62 & 38.56 & 43.70 & 3.93 & 33.80 & 28.74 & 33.30 & 17.03 \\
\hline 2014 & 42.12 & 40.51 & 86.42 & 51.63 & 41.20 & 45.26 & 43.14 & 5.15 & 38.22 & 29.76 & 34.76 & 13.88 \\
\hline 2015 & 36.07 & 36.75 & 83.60 & 52.21 & 39.00 & 45.49 & 40.66 & 4.35 & 36.82 & 32.15 & 35.24 & 12.96 \\
\hline 2016 & 36.56 & 36.24 & 73.11 & 49.26 & 37.53 & 49.02 & 39.15 & 4.05 & 36.29 & 31.07 & 35.40 & 13.51 \\
\hline \multicolumn{13}{|c|}{ TIME VARIABILITY } \\
\hline Dolnośląskie & 12.48 & 12.52 & 7.59 & 5.47 & 7.80 & 11.89 & 8.37 & 5.03 & 4.89 & 5.60 & 2.04 & 4.41 \\
\hline Kujawsko-Pomorskie & 20.59 & 20.74 & 56.76 & 4.88 & 11.47 & 68.76 & 12.58 & 2.29 & 7.38 & 5.77 & 9.70 & 10.76 \\
\hline Lubelskie & 26.20 & 26.63 & 22.64 & 13.02 & 4.32 & 6.95 & 3.01 & 3.20 & 1.81 & 5.31 & 6.01 & 4.14 \\
\hline Lubuskie & 11.61 & 11.78 & 115.47 & 7.59 & 7.71 & 13.61 & 7.49 & 2.78 & 2.72 & 2.24 & 1.67 & 1.72 \\
\hline Łódzkie & 12.73 & 13.20 & 32.60 & 15.06 & 3.90 & 6.48 & 3.75 & 2.72 & 3.50 & 3.19 & 2.35 & 1.69 \\
\hline Małopolskie & 16.47 & 16.21 & 5.97 & 4.02 & 6.75 & 8.67 & 7.00 & 2.41 & 2.29 & 5.25 & 4.06 & 8.79 \\
\hline Mazowieckie & 18.26 & 17.89 & 1.09 & 4.31 & 4.51 & 10.38 & 4.87 & 1.56 & 4.16 & 4.80 & 4.50 & 2.06 \\
\hline Opolskie & 9.42 & 9.89 & 115.47 & 6.09 & 3.65 & 3.56 & 3.65 & 1.29 & 3.33 & 3.11 & 2.28 & 7.06 \\
\hline Podkarpackie & 31.52 & 31.55 & 63.74 & 10.51 & 9.59 & 4.14 & 9.59 & 3.06 & 8.01 & 5.50 & 3.25 & 8.70 \\
\hline Podlaskie & 31.01 & 31.26 & 3.93 & 4.71 & 4.64 & 16.81 & 4.64 & 3.08 & 2.84 & 1.35 & 2.82 & 0.66 \\
\hline Pomorskie & 13.92 & 13.61 & 46.04 & 3.22 & 2.32 & 6.52 & 2.66 & 1.62 & 1.72 & 2.92 & 1.94 & 0.57 \\
\hline Śląskie & 11.91 & 12.29 & 9.77 & 10.61 & 3.65 & 3.81 & 3.86 & 1.17 & 1.27 & 1.81 & 1.66 & 10.68 \\
\hline Świętokrzyskie & 23.57 & 24.06 & 29.89 & 2.66 & 4.96 & 15.03 & 4.96 & 0.64 & 7.89 & 6.44 & 2.91 & 4.12 \\
\hline $\begin{array}{l}\text { Warmińsko- } \\
\text { Mazurskie }\end{array}$ & 26.17 & 26.45 & 37.74 & 8.76 & 1.57 & 2.62 & 2.07 & 2.99 & 4.81 & 3.07 & 6.16 & 11.61 \\
\hline Wielkopolskie & 11.47 & 11.30 & 17.59 & 17.59 & 14.42 & 25.18 & 14.97 & 0.63 & 5.25 & 1.82 & 5.70 & 4.84 \\
\hline Zachodniopomorskie & 13.15 & 13.42 & 69.70 & 0.75 & 7.52 & 18.77 & 7.66 & 1.58 & 2.26 & 1.74 & 3.60 & 5.76 \\
\hline
\end{tabular}

tres per 10000 urban citizens, $X_{8}$ - buses on the move to their inventoried quantity (in \%), $X_{9}$ - the mileage of buses in car-kilometres per 1000 urban citizens, $X_{10}$ - the number of buses per 10000 urban citizens, $X_{11}-$ the number of seats in vehicles (buses, trams, trolleybus) per 1000 urban citizens, $X_{12}$ - the share of buses adapted to the needs of disabled passengers in their total number (in \%).

All of the analysed variables take the form of intensity or structure indicators. Moreover, it should be noted that the set of diagnostic features includes sixteen objects (voivodeships) as well as four years of the analysis. Thus, a three-dimensional data cube has been created. It should be emphasised that it was impossible to extend the analysis to more periods. However, if more years had been taken into the research, less diagnostic variables would have been included in the constructed synthetic measure of urban transport. It should be noted that obtaining the precision data is especially important in logistic research analysing intermodal transport chains (Caris et al., 2014), modelling the travel demand generated by people as well as freight (Cools et al., 2010; Roorda et al., 2010).

Next, the potential set of diagnostic variables was put under statistical investigation containing two stages.

The first stage was connected with variation analysis and the choice of the total taxonomic model. Hence, the classical variation coefficient, which is based on the standard deviation and arithmetic mean, was introduced. The results of the research are presented in Tab. 1.

The results of the variation analysis proved that the feature $X_{8}$ ought to be removed from the further analysis because the variation coefficients were under the threshold value of ten in every year of the research.

In the scope of the assessment of the urban transport development, over the entire period, the total taxonomic measure should be introduced. Hence, three types of taxonomic models, i.e. spatial-time, time-spatial and aggregate, are presented in the literature regarding the overall level of the complex phenomenon under consideration (Młodak, 2005). 
The values of the classic time variation coefficient for every voivodeship over the entire period of analysis are presented in Tab. 1. The investigation proved that the spatial-time taxonomic model should be implemented into the analysis. This situation occurs because the predominance of spatial variation is predominant compared to time variation.

The second stage of the statistical analysis of the potential data set of diagnostic variables is connected with the correlation analysis. In the scope of dealing with that issue, the method of an inverted matrix of Pearson's correlation coefficients was introduced into the research (Malina \& Zeliaś, 1997; Panek \& Zwierzchowski, 2013). The chosen results of the research, i.e. the main diagonals of inverted Pearson correlation matrixes are, presented in Tab. 2.

Moving to the interpretation of the results which are presented in Tab. 2, it should be mentioned that particular variables were eliminated individually. This procedure of the analysis with the inverted correlation matrix is considered appropriate and has already been discussed at the international conference and implemented into the research of living standards (Czech \& Słaby, 2017).

In this case, the research was carried out in four stages separately for each year of the analysis. Nevertheless, the results of stage three proved that more than one variable exceeded the critical and contractual value of ten for all periods. Hence, the feature X10 was excluded from further analysis because of the highest values located on the main diagonal in 2016. Next, the variable $X_{11}$ was eliminated from the set of potential diagnostic variables. However, the results obtained during stage four of the correlation analysis showed that further elimination of diagnostic features could be stopped with a slight deviation from the contractual rule of ten.

To sum up, the final set of diagnostic variables includes the following features: $X_{1}, X_{2}, X_{3}, X_{4}, X_{5}, X_{6}$, $X_{9}, X_{12}$, which were considered as the basis for the construction of synthetic measure for the urban transport in further analysis.

\section{RESEARCH RESULTS}

To bring the final set of diagnostic variables into comparability, the normalisation process was implemented. Furthermore, this transformation was based on both classic as well as order types of standardisation. The first uses the arithmetic mean and standard deviation in its construction, which means the analysis is not immune to the skewness of empirical distributions of particular diagnostic features.

The second approach implements the multidimensional median vector and median absolute deviation as the equivalent of classical measures. The chosen statistical measures of the final set of diagnostic variables which were implemented to the normalisation process are presented in Tab. 3 .

It should be mentioned that the order method with the border median was omitted because this kind of multidimensional median is only immune to skewness but does not consider interactions in the set of diagnostic variables, which is very important from the point of view of the research. Hence, the multidimensional Weber median vector was the basis for normalisation in every year of analysis and supports the construction of the model over the entire period.

Tab. 2. Main diagonals of inverted matrixes of Pearson's correlation coefficients

\begin{tabular}{|c|c|c|c|c|c|c|c|c|c|c|c|c|c|c|c|c|}
\hline & \multicolumn{4}{|c|}{ STAGE I } & \multicolumn{4}{|c|}{ STAGE II } & \multicolumn{4}{|c|}{ StAGE III } & \multicolumn{4}{|c|}{ StAGE IV } \\
\hline & 2013 & 2014 & 2015 & 2016 & 2013 & 2014 & 2015 & 2016 & 2013 & 2014 & 2015 & 2016 & 2013 & 2014 & 2015 & 2016 \\
\hline$x_{1}$ & 4.5 & 4.0 & 3.6 & 5.9 & 4.3 & 3.8 & 3.6 & 5.9 & 2.5 & 3.0 & 3.4 & 4.5 & 2.5 & 2.4 & 2.8 & 3.2 \\
\hline$x_{2}$ & 6.5 & 5.1 & 4.2 & 3.7 & 3.9 & 4.0 & 3.1 & 3.1 & 3.6 & 3.9 & 3.1 & 3.0 & 3.6 & 3.5 & 3.0 & 3.0 \\
\hline$x_{3}$ & 2.5 & 3.1 & 4.4 & 4.9 & 2.5 & 3.1 & 4.3 & 4.9 & 2.4 & 3.1 & 3.6 & 2.6 & 2.4 & 2.9 & 3.5 & 3.4 \\
\hline$x_{4}$ & 6.4 & 4.5 & 8.6 & 8.8 & 6.2 & 4.5 & 6.9 & 8.8 & 6.2 & 4.4 & 6.5 & 8.8 & 3.3 & 2.3 & 2.7 & 2.8 \\
\hline$x_{5}$ & 1064.6 & 972.1 & 855.5 & 546.4 & 13.3 & 15.4 & 14.1 & 14.8 & 5.7 & 11.5 & 13.5 & 12.0 & 5.3 & 11.3 & 11.4 & 9.9 \\
\hline$x_{6}$ & 8.1 & 10.8 & 12.9 & 10.7 & 5.9 & 7.3 & 6.4 & 7.0 & 3.5 & 6.0 & 6.3 & 5.9 & 2.8 & 6.0 & 5.5 & 4.4 \\
\hline$x_{7}$ & 1264.4 & 1188.7 & 1130.3 & 690.0 & - & - & - & - & - & - & - & - & - & - & - & - \\
\hline$X_{g}$ & 21.5 & 13.3 & 40.2 & 47.1 & 21.5 & 12.1 & 29.9 & 35.4 & 7.1 & 7.3 & 9.3 & 10.8 & 4.8 & 5.7 & 5.9 & 6.0 \\
\hline$x_{10}$ & 58.0 & 29.4 & 39.7 & 42.2 & 37.6 & 19.4 & 35.6 & 41.0 & - & - & - & - & - & - & - & - \\
\hline$x_{11}$ & 25.4 & 21.4 & 34.3 & 39.1 & 10.6 & 10.2 & 12.1 & 23.6 & 9.0 & 9.0 & 12.1 & 23.2 & - & - & - & - \\
\hline$x_{12}$ & 3.9 & 4.4 & 8.5 & 4.8 & 2.9 & 3.0 & 4.1 & 3.8 & 2.9 & 2.9 & 3.8 & 3.8 & 2.9 & 2.9 & 3.7 & 3.8 \\
\hline
\end{tabular}


Tab. 3. Chosen statistical measures of the final set of diagnostic variables

\begin{tabular}{|c|c|c|c|c|c|c|c|c|c|}
\hline \multirow{2}{*}{ YEAR } & \multirow{2}{*}{ STATISTICAL MEASURE } & \multicolumn{8}{|c|}{ VARIABLE } \\
\hline & & $x_{1}$ & $x_{2}$ & $x_{3}$ & $x_{4}$ & $x_{5}$ & $x_{6}$ & $x_{9}$ & $x_{12}$ \\
\hline \multirow{4}{*}{2013} & skewness & 0.53 & 0.54 & 0.35 & 1.35 & 1.06 & 0.15 & 0.90 & -0.44 \\
\hline & arithmetic mean & 251.04 & 2.15 & 7.40 & 134.98 & 22.61 & 3.19 & 25.59 & 75.87 \\
\hline & border median & 257.83 & 1.88 & 5.48 & 130.71 & 19.74 & 2.95 & 23.91 & 75.90 \\
\hline & Weber median & 258.42 & 1.97 & 6.78 & 121.43 & 22.19 & 3.59 & 25.67 & 76.28 \\
\hline \multirow{4}{*}{2014} & skewness & 0.52 & 0.27 & 0.46 & 1.23 & 0.98 & 0.11 & 1.20 & -0.80 \\
\hline & arithmetic mean & 301.90 & 2.62 & 7.44 & 139.92 & 22.70 & 3.19 & 26.16 & 80.97 \\
\hline & border median & 299.16 & 2.65 & 5.60 & 125.26 & 19.59 & 3.03 & 23.62 & 83.11 \\
\hline & Weber median & 294.62 & 2.55 & 8.90 & 125.14 & 22.16 & 3.24 & 25.48 & 80.16 \\
\hline \multirow{4}{*}{2015} & skewness & 0.64 & 0.06 & 0.72 & 1.19 & 0.71 & 0.60 & 1.17 & -0.94 \\
\hline & arithmetic mean & 348.48 & 3.07 & 9.26 & 137.78 & 23.19 & 3.34 & 27.03 & 81.68 \\
\hline & border median & 325.13 & 2.93 & 8.01 & 138.60 & 19.40 & 3.07 & 25.13 & 85.16 \\
\hline & Weber median & 327.91 & 2.86 & 10.00 & 130.84 & 23.18 & 3.51 & 26.39 & 80.37 \\
\hline \multirow{4}{*}{2016} & skewness & 0.88 & 0.05 & 0.26 & 0.77 & 0.64 & 1.37 & 1.04 & -0.87 \\
\hline & arithmetic mean & 361.62 & 3.18 & 10.53 & 138.67 & 23.24 & 3.47 & 27.15 & 83.17 \\
\hline & border median & 338.76 & 3.05 & 12.95 & 138.18 & 20.14 & 3.24 & 26.12 & 86.19 \\
\hline & Weber median & 340.44 & 3.06 & 11.59 & 130.47 & 20.97 & 3.52 & 24.65 & 85.12 \\
\hline
\end{tabular}

Moving into the analysis of the presented order location measures, i.e. the border median as well as its Weber form, it should be mentioned that the values differed depending on features. It is the result of including interactions among the variables which are implemented into the description process of urban transport development, in particular, voivodeships. For instance, the border median size for the variable describing the length of bicycle paths per 10000 square kilometres was $338.76 \mathrm{~km}$ in 2016 . However, because of the influence of another variable, the value of the Weber median in the case of the same feature went up and reached $340.44 \mathrm{~km}$ per 10000 square kilometres. It should be mentioned that the differences in the values of these descriptive statistics occur for each year of the analysis.

The process of a complex phenomenon analysis with the construction of the synthetic measure needs a definition of the character of particular features. Hence, the final set of diagnostic variables was divided into two subsets. The first one includes the following features $X_{1}, X_{2}, X_{4}, X_{5}, X_{9}$ and $X_{12}$, which were considered as stimulants. The other consists of the nominants such as $X_{3}$ and $X_{6}$. Nevertheless, it should be noted that destimulants were not recognised in the final set of diagnostic features.

Further, implementation normalized values of the final set of diagnostic features allowed the synthetic measures of urban transport development to be constructed. Their values in classical and order form for particular years of the analysis are presented in Tab. 4 (a, b).

Additionally, the table includes the total measure (general) for the entire period. It was constructed based on synthetic measures for particular years of the analysis in the classic as well as the order form.

Next, they were ordered monotonically and allowed to make a ranking of the urban transport development in voivodeships according to the classical and the order method.

The analysis of the presented rankings proved that positions of some voivodeships were the same. On the other hand, both methods delivered different positions in the ranking for particular years of the analysis.

The values of the synthetic measures can be implemented in the process of indication of similar areas according to the level of urban transport development. In the scope of dealing with that issue, both the three mean and the three median methods can be used (Młodak, 2006). The classical and order examples of this kind of procedure for spatial-time taxonomic models are presented in Fig. 1 as the background of particular voivodeships.

The values of the synthetic measures of urban transport development in its classical and order forms are presented as the height of histograms representing voivodeships for each year of the analysis. 
Tab. 4a. The values of synthetic measures and the positions of voivodships in the ranking of urban transport development

\begin{tabular}{|c|c|c|c|c|c|c|c|c|c|c|}
\hline \multirow{3}{*}{ VOIVODESHIP } & \multicolumn{10}{|c|}{ VALUE OF SYNTHETIC MEASURE } \\
\hline & \multicolumn{2}{|c|}{2013} & \multicolumn{2}{|c|}{2014} & \multicolumn{2}{|c|}{2015} & \multicolumn{2}{|c|}{2016} & \multicolumn{2}{|c|}{ TOTAL } \\
\hline & MK & $M P$ & MK & $M P$ & $M K$ & MP & MK & $M P$ & MK & $M P$ \\
\hline Dolnośląskie & 0.27 & 0.21 & 0.32 & 0.23 & 0.29 & 0.13 & 0.26 & 0.16 & 0.53 & 0.25 \\
\hline Kujawsko-Pomorskie & 0.25 & 0.21 & 0.26 & 0.19 & 0.28 & 0.14 & 0.35 & 0.23 & 0.53 & 0.28 \\
\hline Lubelskie & 0.18 & 0.12 & 0.21 & 0.12 & 0.20 & 0.04 & 0.26 & 0.16 & 0.39 & 0.11 \\
\hline Lubuskie & 0.33 & 0.25 & 0.28 & 0.16 & 0.25 & 0.06 & 0.25 & 0.09 & 0.51 & 0.15 \\
\hline Łódzkie & 0.30 & 0.24 & 0.27 & 0.20 & 0.27 & 0.15 & 0.27 & 0.19 & 0.51 & 0.28 \\
\hline Małopolskie & 0.25 & 0.24 & 0.24 & 0.21 & 0.21 & 0.11 & 0.20 & 0.14 & 0.42 & 0.23 \\
\hline Mazowieckie & 0.52 & 0.54 & 0.51 & 0.50 & 0.53 & 0.52 & 0.59 & 0.61 & 1.00 & 1.00 \\
\hline Opolskie & 0.05 & -0.02 & 0.04 & -0.06 & 0.02 & -0.16 & 0.01 & -0.13 & 0.05 & -0.31 \\
\hline Podkarpackie & 0.10 & 0.03 & 0.05 & -0.03 & 0.11 & -0.06 & 0.12 & 0.01 & 0.17 & -0.13 \\
\hline Podlaskie & 0.16 & 0.13 & 0.18 & 0.11 & 0.26 & 0.13 & 0.27 & 0.18 & 0.40 & 0.18 \\
\hline Pomorskie & 0.48 & 0.45 & 0.51 & 0.43 & 0.47 & 0.34 & 0.50 & 0.37 & 0.91 & 0.68 \\
\hline Śląskie & 0.36 & 0.34 & 0.33 & 0.29 & 0.36 & 0.26 & 0.41 & 0.37 & 0.67 & 0.53 \\
\hline Świętokrzyskie & 0.21 & 0.19 & 0.20 & 0.18 & 0.16 & 0.11 & 0.21 & 0.25 & 0.36 & 0.26 \\
\hline Warmińsko-Mazurskie & 0.07 & -0.02 & 0.13 & 0.02 & 0.09 & -0.10 & 0.10 & -0.06 & 0.18 & -0.19 \\
\hline Wielkopolskie & 0.36 & 0.31 & 0.42 & 0.34 & 0.32 & 0.14 & 0.33 & 0.17 & 0.66 & 0.34 \\
\hline Zachodniopomorskie & 0.24 & 0.20 & 0.26 & 0.17 & 0.23 & 0.08 & 0.30 & 0.17 & 0.47 & 0.20 \\
\hline
\end{tabular}

Note: $M K$ - classical measure, $M P$ - order measure.

Tab. 4b. The values of synthetic measures and the positions of voivodships in the ranking of urban transport development

\begin{tabular}{|c|c|c|c|c|c|c|c|c|c|c|}
\hline \multirow{3}{*}{ VOIVODESHIP } & \multicolumn{10}{|c|}{ RANK } \\
\hline & \multicolumn{2}{|c|}{2013} & \multicolumn{2}{|c|}{2014} & \multicolumn{2}{|c|}{2015} & \multicolumn{2}{|c|}{2016} & \multicolumn{2}{|c|}{ TOTAL } \\
\hline & Mк & $M P$ & Mк & $M P$ & мк & $M P$ & Mк & $M P$ & MK & $M P$ \\
\hline Dolnośląskie & 7 & 9 & 5 & 5 & 5 & 7 & 10 & 11 & 6 & 8 \\
\hline Kujawsko-Pomorskie & 8 & 8 & 8 & 8 & 6 & 5 & 4 & 5 & 5 & 6 \\
\hline Lubelskie & 12 & 13 & 11 & 12 & 12 & 13 & 9 & 10 & 12 & 13 \\
\hline Lubuskie & 5 & 5 & 6 & 11 & 9 & 12 & 11 & 13 & 7 & 12 \\
\hline Łódzkie & 6 & 6 & 7 & 7 & 7 & 4 & 7 & 6 & 8 & 5 \\
\hline Małopolskie & 9 & 7 & 10 & 6 & 11 & 10 & 13 & 12 & 10 & 9 \\
\hline Mazowieckie & 1 & 1 & 2 & 1 & 1 & 1 & 1 & 1 & 1 & 1 \\
\hline Opolskie & 16 & 16 & 16 & 16 & 16 & 16 & 16 & 16 & 16 & 16 \\
\hline Podkarpackie & 14 & 14 & 15 & 15 & 14 & 14 & 14 & 14 & 15 & 14 \\
\hline Podlaskie & 13 & 12 & 13 & 13 & 8 & 8 & 8 & 7 & 11 & 11 \\
\hline Pomorskie & 2 & 2 & 1 & 2 & 2 & 2 & 2 & 2 & 2 & 2 \\
\hline Śląskie & 3 & 3 & 4 & 4 & 3 & 3 & 3 & 3 & 3 & 3 \\
\hline Świętokrzyskie & 11 & 11 & 12 & 9 & 13 & 9 & 12 & 4 & 13 & 7 \\
\hline Warmińsko-Mazurskie & 15 & 15 & 14 & 14 & 15 & 15 & 15 & 15 & 14 & 15 \\
\hline Wielkopolskie & 4 & 4 & 3 & 3 & 4 & 6 & 5 & 9 & 4 & 4 \\
\hline Zachodniopomorskie & 10 & 10 & 9 & 10 & 10 & 11 & 6 & 8 & 9 & 10 \\
\hline
\end{tabular}

Note: $M K$ - classical measure, $M P$ - order measure. 


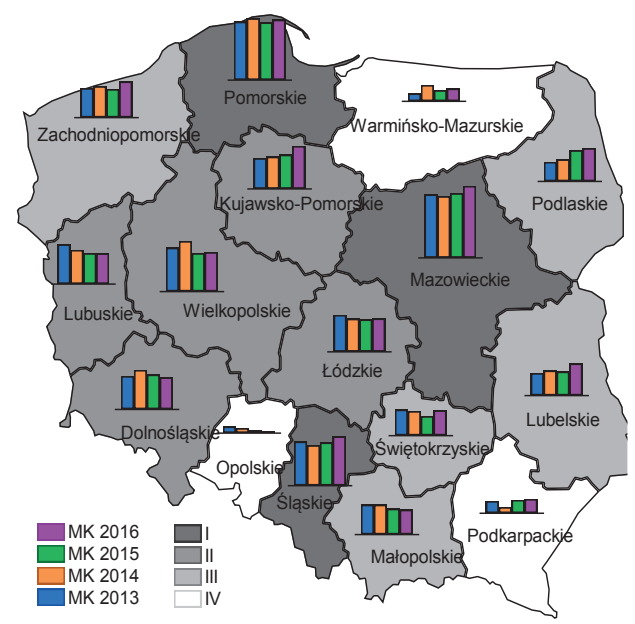

MK

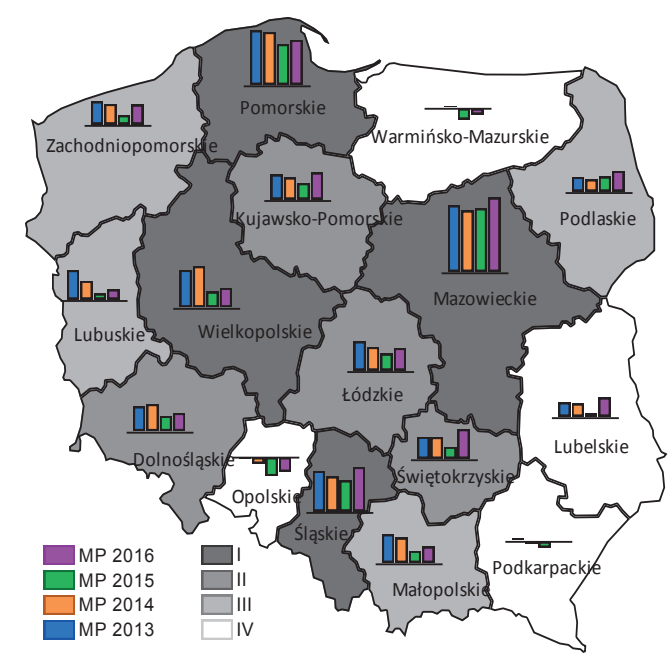

MP

Fig. 1. Diversification of urban transport development in Poland in 2013-2016

Note: the background of voivodeships - the spatial-time model (the total measure), the height of the histogram - the values of synthetic measures in particular years of the analysis, $M K-$ the classical measure, $M P$ - the order measure.

All in all, the graphical presentation of the research shows that the general (total) classification of provinces to particular groups of urban transport development differs because of the included interactions among diagnostic features.

\section{DISCUSSION OF THE RESULTS}

The research with the use of the synthetic measure of the urban transport development in selected Polish provinces has brought up some interesting findings in two main areas, namely, logistics and statistics.

The first area includes comments regarding the spatial objects, i.e. voivodeships which were included in the research. It should be noted that the quantitative assessment of the urban transport development in selected voivodeships is somewhat a complex task. The research targeted the period 2013-2016 and proved the disparity among development levels of the urban transport development in all sixteen provinces.

Both the classical as well as the order synthetic measures can be considered as the most important indicators which can be used in the assessment process. Furthermore, the analysis proved that the leaders of urban transport development were the same voivodeships over the entire period.
On the one hand, both the classical as well as the order measures indicated that the Mazowieckie voivodeship was the leader over the whole period. However, this province was ranked second according to the classical measure only in 2014. The first place was occupied by the cities located in the Pomorskie voivodeships.

The second position in the constructed ranking of urban transport development over the entire period was occupied by the Pomorskie province. It should also be noted that the Śląskie province can be considered as the third object in the constructed ranking.

However, besides the mentioned leaders, namely the provinces of Mazowieckie, Pomorskie and Śląskie, the fourth position according to the both of the constructed total synthetic measures of the urban transport development was occupied by the Wielkopolskie voivodeship. It should be noted that its position changed depending on years of the analysis, e.g. it had the third place in 2014 according to both measures, and the fifth and sixth positions in 2016, etc.

In the scope of the analysis over the entire period, i.e. the total measure in the analysis the following voivodeships were indicated: the Mazowieckie, Pomorskie, Śląskie and Wielkopolskie provinces took the first, second, third and fourth positions.

The research demonstrated that the lower positions in the urban transport development ranking constructed using the final set of diagnostic variables 
were occupied by the Warmińsko-Mazurskie and Podkarpackie provinces.

Opolskie voivodeship took the 16 th position in the ranking both according to the classical and the order measure. The Warmińsko-Maziurskie voivodeship took the 13th position in 2014. However, it was in the 15th place in the general classification, which is based on the total synthetic measure. The Podkarpackie province occupied a distant position.

The analysis of the data presented in Tab. 4 proved both the fluctuations and significant differences in the level of the urban transport development among some voivodeships. The Świętokrzyskie voivodeship can serve as an example. It takes the 13th position in the general classification according to the classic measure. However, it ranked the seventh using the order measure with the Weber median.

Similar differences can be observed in relation to the Łódzkie province which takes the eight and fifth positions according to the classical and the order measures, respectively.

To sum up, the analysis of the general (total) classification proved that the same positions in the ranking of urban transport development were observed in six analysed provinces. Hence, the Mazowieckie, Oplskie, Podlaskie, Pomorskie and Wielkopolskie provinces can be considered as such spatial objects. All in all, the differences in the constructed rankings are observed in the remaining ten regions of Poland. This phenomenon can be noticed in the following provinces, such as Zachodniopomorskie, WarmińskoMazurskie, Podkarpackie, Małopolskie, Lubelskie and Kujawsko-Pomorskie. Nevertheless, the difference between the two positions appeared only in the Dolnośląskie voivodeship.

The latter set of findings reflects the statistical observations related to the construction of the synthetic measure of the urban transport development in selected voivodeships.

However, the research was strongly limited by the availability of data. Adding more years to the analysis would have included less diagnostic variables.

The analysis of the variation demonstrated that the variable $X_{8}$, which was connected with the share of buses on the move to their inventoried quantity, poorly differentiated the research objects. The values of that indicator for provinces were very high, which reflects good use and low failure rate of the bus fleet. Moreover, the variation analysis of the potential set of diagnostic variables proved that the spatial-time approach should be introduced in the construction of the total synthetic measure.

However, it should be noted that the potential set of diagnostic features was mainly limited during the correlation analysis and particular features should be eliminated individually.

The research results showed that the implementation of the order synthetic measure with the Weber median allowed including additional indirectly observed information in the complex urban transportation system and made some differences in the constructed rankings.

\section{CONCLUSIONS}

The results obtained in this research produced several synthetic conclusions about the urban transport development in particular voivodeships as a part of the national logistics system.

In the total measure, i.e. the spatial-time, the higher and more stable positions were occupied by the Mazowieckie, Pomorskie and Śląskie provinces. One should expect that the level of the following variables $X_{1}, X_{2}, X_{4}, X_{5}, X_{9}, X_{12}$ that are considered as stimulants is relatively high.

The research demonstrated that such voivodeships as Opolskie, Warmińsko-Mazurskie and Podkarpackie remain at the other end of the development level and take the last three positions in the ranking. In conclusion, they require special attention of the local and state governments. It should also be emphasised that the urban transport in these areas reached a relatively low level of development. Hence, an improvement could be expected following investments in the development of stimulants that were introduced into the synthetic measure construction.

To sum up, the research shows some correctness of the spatial development of the country which can be reflected in the urban development level. The voivodeships located in the eastern regions of Poland can be considered as more underdeveloped. Nevertheless, the Opolskie province can be treated as the exception to the rule. This is due to the observed emigration of the local citizens to Germany as well as low level of investments. 


\section{LITERATURE}

Ahmad, S., \& Puppim de Oliveira, J. A. (2016). Determinants of urban mobility in India: Lessons for promoting sustainable and inclusive urban transportation in developing countries. Transport Policy, 50, 106-114.

Бездудная, А. Г., \& Фраймович, Д. Ю. (2016). Диагностика эффективности инвестиций в воспроизводственных процессах региональных инновационных систем [Diagnostics of investment efficiency in the reproductive processes of regional innovation systems]. Конкурентоспособность в Глобальном Мире: Экономика, Наука, Технотогии, 7(1), 35-39.

Caris, A., Limbourg, S., Macharis, C., van Lier, T., \& Cools, M. (2014). Integration of inland waterway transport in the intermodal supply chains: a taxonomy of research challenges. Journal of Transport Geography, 41, 126-136.

Cheba, K. (2011). Taksonomiczna analiza rozwoju transportu drogowego w Polsce [Taxonomic analysis of road transport development in Poland]. Logistyka, 2, 97-106.

Cheba, K., \& Saniuk, S. (2015). Kreowanie mobilności mieszkańców miast jako nowy obszar wartości miasta [Creating mobility of urban residents as a new area of the city's value]. Studia Ekonomiczne. Zeszyty Naukowe Uniwersytetu Ekonomicznego w Katowicach, 249, 134-144.

Cheba, K., \& Saniuk, S. (2016). Sustainable urban transport - the concept of measurement in the field of city logistics. Transportation Research Procedia, 16, 35-45.

Cools, M., Moons, E., \& Wets, G. (2010). Calibrating activity-based models with external origin-destination: overview of possibilities. Transportation Research Record: Journal of the Transportation Research Board, 2175, 98-110.

Czech, A. (2014). Application of chosen normalization methods in the process of construction of synthetic measure in indirect consumption research. Folia Oeconomica, 3(302), 231-240.

Czech, A., \& Lewczuk, J. (2016). Taxonomic and econometric analysis of road transport development in Poland - the voivodship approach. Economics and Management, 4(4), 88-100.

Czech, A., Lewczuk, J., \& Bortłomiuk, A. (2016). Multidimensional assessment of the European Union transport development in the light of implemented normalization methods. Economics and Management, 8(4), 75-85.

Czech, A., \& Lewczuk, J. (2017). Statistical assessment of the development of the transportation system in chosen countries - an international approach. Procedia Engineering, 182, 112-119.

Czech, A., \& Słaby, T. (2017). Ocena poziomu życia gospodarstw domowych według województw - meandry analizy taksonomicznej [The assessment of Polish households living standards in voivodeships - the meanders of taxonomic analysis]. Wiadomości Statystyczne, 10(677), 19-37.
Dębkowska, K., \& Jarocka, M. (2013). The impact of the method of the data normalization on the results. Folia Oeconomica, 286, 181-188.

Domański, C., Pruska, K., \& Wagner, W. (1998). Wnioskowanie statystyczne przy nieklasycznych założeniach [Statistical estimation with non-classical assumptions]. Łódz, Poland: University of Łodz.

Ducret, R., Lemarié, B., \& Roset, A. (2016). Cluster analysis and spatial modeling for urban fright. Identifying homogeneous urban zones based on urban form and logistics characteristics. Transportation Research Procedia, 12, 301-313.

Ejdys, J., Nazarko, J., Nazarko, Ł., \& Halicka, K. (2015). Foresight application for transport sector. In M. Fiorini, J. Jia-Chin Lin (Eds.), Clean mobility and Intelligent Transport Systems (pp. 379-402). London, England: The Institution of Engineering and Technology.

European Commission. (2011). White Paper on Transport. Roadmap to a Single European Transport Area Towards a competitive and resource efficient transport system. Luxembourg: Publications Office of the European Union.

Ewing, R., \& Cervero, R. (2001). Travel and the built environment: A synthesis. Transportation Research Record, 1780, 87-113.

Fanni, Z., Khakpour, B. A., \& Heydari, A. (2014). Evaluating the regional development of border cities by TOPSIS model (case study: Sistan and Baluchistan Province, Iran). Sustainable Cities and Society, 10, 80-86.

Figura, J. (2013). Taksonomia w polityce logistycznej państwa [Taxonomy in logistic policy of state]. Katowice, Poland: Uniwersytet Ekonomiczny.

Gratiela, B. (2013). Analysis of transport's external costs in the European Union. Constanta Maritime University Annals, 14(20), 213-216.

Hajduk, S. (2016). Assessment of urban transport - a comparative analysis of selected cities by taxonomic methods. Economics and Management, 8(4), 67-74.

Hajduk, S. (2017). Bibliometric analysis of publications on city logistics in international scientific literature. Procedia Engineering, 182, 282-290.

Hayashi, Y., \& Morisugi, H. (2000). International comparison of background concept and methodology of transportation project appraisal. Transport Policy, 7, 73-88.

Hellwig, Z. (1968). Zastosowanie metody taksonomicznej do typologicznego podziału krajów ze względu na poziom ich rozwoju oraz zasoby i strukturę wykwalifikowanych kadr [Application of the taxonomy method to typology classification of the countries because of the development level or resources and the structure of human resources]. Przeglad Statystyczny, 4, 307-327.

Ignacy, J. (2016). Wrocław Agglomeration attractiveness as a source of competitive advantage for enterprises. Journal of Management and Financial Sciences, 9(24), 147-160. 
Jahanshahi, K., Jin, Y., \& Williams, I. (2015). Direct and indirect influences on employed adults' travel in the UK: New insights from the National Travel Survey data 2002-2010. Transportation Research Part A, 80, 288-306.

Jajuga, K., \& Walesiak, M. (2000). Standardization of data set under different measurement scales. In R. Decker, W. Gaul (Eds.), Classification and information processing at the turn of the millennium (pp. 105-112). Berlin, Germany: Springer-Verlag.

Jarocka, M., \& Glińska, E. (2017). The state and prospects for development of railway transport infrastructure in Eastern Poland - secondary data analysis. Procedia Engineering, 182, 299-305.

Kauf, S., \& Tłuczak, A. (2014). Spatiotemporal estimation of the logistic structure differentiation in the European Union country. Proceedings of MAC-EMMT, 1, 14-19.

Kherbash, O., \& Liviu Mocan, M. (2015). A review of logistic and transport sector as a factor of globalization. Procedia Economics and Finance, 27, 42-47.

Korczak, J., \& Kijewska, K. (2016). The concept of sustainable development of public passenger transport in Koszalin. Transportaion Research Procedia, 16, 217 226.

Kozera, A., Stanisławska, J., \& Wysocki, F. (2014). Sytuacja finansowa gospodarstw domowych zamieszkujących obszary wiejskie w Polsce po wstąpieniu Polski do Unii Europejskiej [The Financial Situation of Households in Rural Areas in Poland in the Context of European Integration]. Roczniki Naukowe Ekonomii Rolnictwa i Rozwoju Obszarów Wiejskich, 101(2), 91-101.

Kumar, S., \& Hoffmann, J. (2002), Globalization: the Maritime nexus. In C. Grammenos (Ed.), Handbook of Maritime Economics and Business (pp. 35-62). London, England: Loyds List Press.

Lewczuk, J., \& Ustinovichius, L. (2015). The concept of multi-functional development of cross-border regions: Poland case. Procedia Engineering, 122, 65-70.

Liberadzki, B. (2013). Fiskalizm a strategiczne cele transportu [Fiscalism and strategical aims of transport]. Studia $i$ Prace Kolegium Zarządzania $i$ Finansów SGH, 123, 11-16.

Lira, J., Wagner, W., \& Wysocki, F. (2002). Mediana w zagadnieniach porządkowania obiektów wielocechowych [Median in the ordering issues of multivariable objects]. In W. J. Paradysz (Ed.), Statystyka regionalna $w$ stużbie samorzadu lokalnego i biznesu [Regional statistics in duty of local government], (pp. 87-99). Poznań, Poland: Internetowa Oficyna Wydawnicza Centrum Statystyki Regionalnej, \& Wydawnictwo Akademii Ekonomicznej w Poznaniu.

Madras, T., \& Mitura, M. (2014). Dochody własne miast wojewódzkich w analizie ich kondycji finansowej [Own-sources revenues of voivodeship capital cities in the analysis of their financial condition]. Ekonomia i Zarzadzanie, 6(4), 123-134.
Максимцев, И. А., Межевич, И. А., \& Разумовский В. М. (2017). Мировая экономика перед вызовами Annus Horribilis: на пороге новой регионализации [The world economy facing the challenges Annus Horribilis: on the threshold of a new regionalization]. Известия Санкт-Петербургского Государственного Экономического Университета, 1(103), 107 114.

Malasek, J. (2016). A set of tools for making urban transport more sustainable. Transportation Research Procedia, 14, 876-885.

Malina, A., \& Zeliaś, A. (1997). On building taxsonometric measure of living conditions. Statistics in Transitions, 3(3), 523-544.

Matteis, T., Liedtke, G., \& Wisetjindawat, W. (2016). A framework for incorporating market interactions in an agent based model for freight transport. Transportation Research Procedia, 12, 925-937.

Młodak A. (2005). Ocena zmienności cech statystycznych $\mathrm{w}$ modelu taksonomicznym [The evaluation of the variability of statistical features in the taxonomic model]. Wiadomości Statystyczne, 9, 5-18.

Młodak, A. (2006). Analiza taksonomiczna $w$ statystyce regionalnej [Taxonomic analysis in regional policy]. Warszawa, Poland: Difin.

Młodak, A. (2009). Historia problemu Webera [The history of Weber issue]. Matematyka Stosowana, 10(51), 3-21.

Mun, S., \& Nakagawa, S. (2010). Pricing and investment of cross-border transport infrastructure. Regional Science and Urban Economics, 40, 228-240.

Olszewska, A. M., \& Gudanowska, A. E. (2014). Wykorzystanie wybranych metod porządkowania obiektów do klasyfikacji województw pod kątem ich potencjału innowacyjnego. Metody Ilościowe w Badaniach Ekonomicznych, 15(4), 91-100.

Paprocki, W. (2013). Reakcje uczestników rynku transportowego na wzrost obciążeń fiskalnych - analiza na przykładzie wprowadzenia viaTOLL [Reactions of transportation market to the increase of fiscal burden - viaTOLL introduction analysis]. Studia $i$ Prace Kolegium Zarządzania i Finansów SGH, 123, 17-33.

Panek, T., \& Zwierzchowski, J. (2013). Statystyczne metody wielowymiarowej analizy porównawczej. Teoria $i$ zastosowania [Statistical methods of multivariate comparative analysis. Theory and practice]. Warszawa, Poland: Oficyna Wydawnicza SGH.

Persia, L., Cipriani, E., Sgarra, V., \& Meta, E. (2016). Strategies and measures for sustainable transport systems. Transportation Research Procedia, 14, 955-964.

Puppim de Oliveira, J. A., Jing, Y., \& Collins, P. (2015). Public administration for development: trends and the way forward. Public Administration and Development, 35(2), 65-72.

Radziszewski, P., Nazarko, J., Vilutiene, T., Dębkowska, K., Ejdys, J., Gudanowska, A., Halicka, K., Kilon, J., Kononiuk, A., Kowalski, K. J., Król, J. B., Nazarko, Ł., \& Sarnowski, M. (2016). Future trends in road pavement technologies development in the context of environmental protection. Baltic Journal of Road and Bridge Engineering, 11(2), 160-168. 
Roorda, M. J., Cavalcante, R., McCabe, S., \& Kwan, H. (2010). A conceptual framework for agent-based modeling of logistic services. Transportation Research Part E: Logistics and Transportation Review, 46(1), 18-31.

Sánchez-Diaz, I., Holguin-Veras, J., \& Wang, X. (2014). An exploratory analysis of spatial effects on fright trip attraction. Transportation, 43, 177-196.

Solecka, K. (2011). Integration of public transport in Polish and EU documents and examples of solutions for integration of public transport in Poland and in the world. Transport problems, 6(4), 23-34.

Steal, D., \& Marshall, S. (2001). The relationship between urban form and travel patterns. An international review and evaluation. European Journal of Transport and Infrastructure Research, 1(2), 113-141.

Strojny, J. (2013). Zastosowanie taksonomii struktur do analizy ewolucji system transport towarowego w krajach Unii Europejskiej [Using taxonomy of structures to analyze the evolution of the freight transport system in the European Union]. Wiadomości Statystyczne, 10, 53-66.

Tarka, D. (2012). Infrastruktura transportowa w wybranych krajach Unii Europejskiej - analiza taksonomiczna [Transportation infrastructure in EU countries taxonomic analysis]. Ekonomia i Zarządzanie, 4(4), 88-100.

Ustinovichius, L., Lewczuk, J., \& Czech, A. (2017). Methodological approach justifying the concept of crossborder and trans boundary cooperation with other countries and regions. Procedia Engineering, 208, 183-189.

Vörös, T., Juhász, M., \& Koppány, K. (2015). The measurement of indirect effects in project appraisal. Transportation Research Procedia, 13, 114-123.

Ward, E. J., Dimitriou, H. T., \& Dean, M. (2016). The application of policy-led multi-criteria analysis to mega transport infrastructure project appraisal. Research in Transportation Economics, 58, 21-45. 